Article

\title{
Norwegian Pitched Roof Defects
}

\author{
Lars Gullbrekken $^{1, *}$, Tore Kvande ${ }^{1}$, Bjørn Petter Jelle ${ }^{1,2}$ and Berit Time ${ }^{2}$ \\ 1 Department of Civil and Transport Engineering, Norwegian University of Science and Technology (NTNU), \\ NO-7491 Trondheim, Norway; tore.kvande@ntnu.no (T.K.); bjorn.petter.jelle@sintef.no (B.P.J.) \\ 2 Department of Materials and Structures, SINTEF Building and Infrastructure, NO-7465 Trondheim, Norway; \\ berit.time@sintef.no \\ * Correspondence: lars.gullbrekken@sintef.no; Tel.: +47-45474324
}

Academic Editor: Francisco López Almansa

Received: 1 April 2016; Accepted: 16 June 2016; Published: 21 June 2016

\begin{abstract}
The building constructions investigated in this work are pitched wooden roofs with exterior vertical drainpipes and wooden load-bearing system. The aim of this research is to further investigate the building defects of pitched wooden roofs and obtain an overview of typical roof defects. The work involves an analysis of the building defect archive from the research institute SINTEF Building and Infrastructure. The findings from the SINTEF archive show that moisture is a dominant exposure factor, especially in roof constructions. In pitched wooden roofs, more than half of the defects are caused by deficiencies in design, materials, or workmanship, where these deficiencies allow moisture from precipitation or indoor moisture into the structure. Hence, it is important to increase the focus on robust and durable solutions to avoid defects both from exterior and interior moisture sources in pitched wooden roofs. Proper design of interior ventilation and vapour retarders seem to be the main ways to control entry from interior moisture sources into attic and roof spaces.
\end{abstract}

Keywords: wood; roof; pitched; climate; robustness; moisture

\section{Introduction}

\subsection{Wood Building Traditions and Climate Exposure}

In the Nordic countries, many buildings have wooden frames. Such constructions are especially common for small houses. There is a well-developed tradition of using wood for exterior cladding, load-bearing systems, and interior cladding. In roof constructions, wood is mainly used for the load-bearing systems, which in the following paper are referred to as wooden roofs. The wood-based building tradition has developed due to easy access to high-quality raw materials. A favorable carbon footprint, a strong focus on $\mathrm{CO}_{2}$ emissions from buildings, and consequent development of zero emission buildings make wooden roofs suitable for an increasing number of buildings. However, the use of wood in buildings may not always be favourable due to robustness issues and climate exposure (e.g., mould, rot, built-in moisture). This means a special focus is needed to develop wooden building technology.

Norway is characterized by an extremely varied climate, the rugged topography being one of the main reasons for large local differences over short distances and extreme seasonal variations [1]. The climate puts a great demand on the building envelope of Norwegian buildings. The building envelope and the roof in particular may be exposed to severe winds, snow loads, precipitation, freeze/thaw cycles, and rather large temperature fluctuations. The climate exposure strongly affects the durability of the roof materials and the long life performance of the roof constructions.

Measures to adapt the built environment to the anticipated climate changes were studied by [2]. They stress the immediate need for information and research both with respect to sensitivities in the built environment and technical solutions to prevent or minimize negative climatic impacts on 
buildings. According to [3], the yearly Norwegian precipitation will increase $10 \%-20 \%$ depending on the climatic model used, which will put extra stress on roof constructions in particular.

\subsection{Building Defects and Robustness}

Building materials have to fulfil several demands during the lifetime of the various products. Consequently, it is important to select building materials which are proven to be durable [4]. This will also be important when utilizing new materials and technologies in the building envelope, like building integrated photovoltaics (BIPV) [5-7]. The lack of data on long-term durability can be compensated for by using accelerated ageing test methods [4].

A method to classify robustness of buildings and their components was studied by [8]. Their study recommends a framework for a robustness classification method for building materials, building assemblies and whole buildings taking into account service life and climate exposure. The robustness of a building or a building component will relate to the exposed climate as well as the intended service life. The study was general and the robustness of roof constructions was not treated in detail. Nevertheless, the suggested definition of robustness is also relevant for the work presented herein: "Materials and solutions having a high resistance against failure (e.g., moisture problems), and having a high probability of being constructed according to specifications. The service life of the materials and solutions will also be important" [8].

The yearly costs caused by process-induced building defects are about $4 \%( \pm 2 \%)$ of the total yearly investments into new buildings (both residential and commercial) in Norway [9]. Process-induced building defects are defined as the "absence or reduction of presupposed quality which is observed after a construction project is finished and handed over to the owner, and which he demands to be repaired" [10]. Process-induced building defects therefore bring about exceptional maintenance and repair costs (i.e., costs that should not have occurred). Many of these defects are located in the roofs. In the following discussions, the term "source of defect" is related to the exposure from the environment rather than material failure, improper design, and workmanship which is also causing the building defect.

In Norway, process-induced building defects have been studied by [11]. A comprehensive analysis of building defects was carried out by systematically investigating SINTEF's archive of building defect documents. The building defect documents are prepared both through extensive field investigations and on behalf of the construction and building industry. A total of 2423 cases described in 2003 reports were studied for the 10-year period from 1993 to 2002. Process-induced building defect cases relating to the building envelope accounted for $66 \%$ of the investigated defect cases. Moisture was the main cause of defects, accounting for $76 \%$ of the 2423 cases. This includes all types of construction defects, including roofs, which represented $22 \%$ of the total defects. However, a thorough study of roof defects has not previously been conducted. Hence, this study looks more thoroughly into the cases concerning roof defects covered by [11,12].

\subsection{Objective and Scope}

The aim of this research has been to further investigate the SINTEF building defects archive of pitched wooden roofs and obtain an overview of typical roof defects and common sources (critical exposure). The building defect analysis is adding to the study of $[11,12]$ following the process induced building defects definition proposed by $[10,11]$.

SINTEF's building defect archive classifies pitched roof constructions into the following four types: (A) pitched wooden roofs with separate wind barrier and underlayer roof (venting air cavity between wind barrier and underlayer roof), (B) pitched wooden roofs with combined underlayer roof and wind barrier, also known as watertight vapour open membrane, (C) pitched wooden roofs with cold attics, and (D) pitched wooden roofs with heated rooms in parts of the attic. "Wooden roof" is defined by the wood based load-bearing system of the roof according to [13]. Defects on roof construction types A, B, C, and D are compared with defects on compact roofs and terraces. 


\section{Pitched Wooden Roof Constructions}

The constructions treated in this work are pitched roofs with exterior vertical drainpipes and wood based load bearing system. The various design principles for wooden roofs are thoroughly discussed in [13]. The principles below are presented in the order given in the SINTEF building defect archive.

\subsection{Design Principles}

The basic principle is that the roof construction must be ventilated in order to transport:

(1) moisture from the roof, and thus prevent mould growth and other moisture damage; and

(2) heat, and thus prevent unwanted melting of snow and ice at the eaves and gutters.

This work is limited to the following roof construction types (see also Figures 1-4):

A A Pitched wooden roofs with separate wind barrier and underlayer roof (ventilation air cavity between wind barrier and underlayer roof).

B Pitched wooden roofs with combined underlayer roof and wind barrier (watertight vapour open membrane).

C Pitched wooden roofs with cold attics.

D Pitched wooden roofs with heated rooms in parts of the attic.

\subsection{Type A-Pitched Wooden Roof with Separate Wind Barrier and Underroof}

Roof construction Type A is a typical roof built before the year 2000 (see Figure 1). The outer part of the roof consists of:

- raintight roofing;

- drainage and ventilation cavity;

- vapour-tight underlayer roof;

- ventilation cavity; and

- vapour open wind barrier.

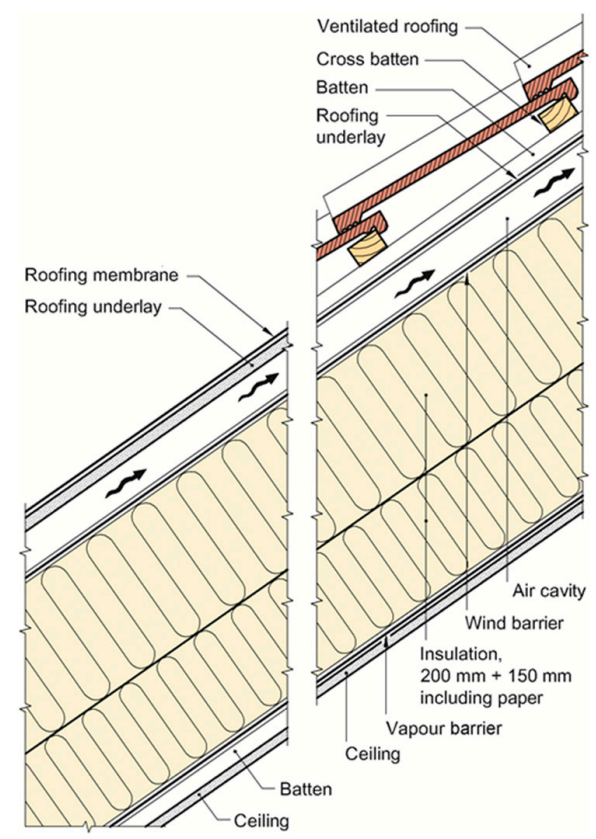

Figure 1. Roof Type A, which separates the rain and wind barrier [13]. Here shown with two common types of roofing. 
Type A separates the rain and wind barrier with roofing directly on wooden sheets or with the roofing and underlayer above a separate wind barrier. The roof is ventilated both between the wind barrier and rain barrier and between the rain barrier and the roofing. The rain barrier can be vapour tight. This detail results in additional materials and often higher labour costs compared with the more developed and modern construction of Type B (see Figure 2).

\subsection{Type B-Pitched Wooden Roofs with Combined Wind Barrier and Underlayer Roof}

Type B is a development of Type A and an improved roof design (see Figure 2). The outer part of the roof construction consists of:

- $\quad$ raintight roofing;

- drainage and ventilation cavity; and

- combined vapour open and watertight wind barrier and underlayer roof.

The main difference between Type A and B is that the drainage and ventilation of Type B is performed directly under the roofing. Both roof types are thermally insulated between the wood rafters. However, the thermal insulation in roof Type B can be placed directly under the underlayer roof because the underlayer roof is a sufficiently vapour open and watertight wind barrier. A study done by [14] involved laboratory measurements of the performance of a combined wind barrier and underroof in driving rain. The measurements concluded that holes in the battens caused by fixing screws or nails are possible leakage locations in such roofs. The problem can be limited by use of special gaskets between the underlayer roofing and the batten [14].

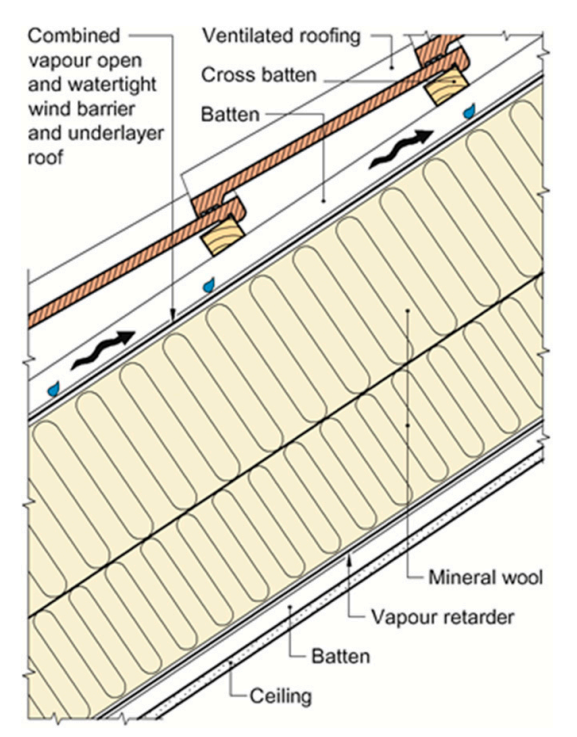

Figure 2. Roof Type B, which is an insulated pitched wooden roof with vapour open combined wind barrier and underlayer roof. All ventilation of the roof takes place in the air cavity below the roofing [13].

\subsection{Type C-Pitched Wooden Roofs with Cold Attics}

Type $C$ consists of roofs with an air volume (attic) between the insulation and the roofing. During most of the year, the air temperature in the attic will be close to the ambient temperature, but during sunny summer days, the temperatures in the attic can be higher than the ambient temperature. The roof with cold attics can be built up in two different ways (see Figure 3):

(a) Cold, ventilated attic space with air stream flowing through the attic itself. The underlayer roof may be vapour tight. There are ventilation openings in the ridge and between the underlayer roof and the thermal insulation along the eaves of the building. Ventilation openings have to be 
designed in order to avoid penetration of snow and rain into the attic. Only the vapour retarder contributes to the airtightness of the building (ceiling), making the solution vulnerable to holes and imperfections in the vapour retarder, which again can cause condensation because of air (containing moisture) leakages through the construction. Hagentoft et al. [15] found that the moisture level of cold ventilated lofts is improved if the attic floor is airtight, has low built-in moisture content, and has well-ventilated indoor air.

(b) Cold, unventilated attic space with all ventilation between the underlayer roof and roof covering. The construction is a further development of a) and an improved roof design. The underlayer roof is a vapour open and watertight wind barrier. Both the wind barrier and vapour retarder should be used continuously, thus making it easier to ensure airtightness of the building.
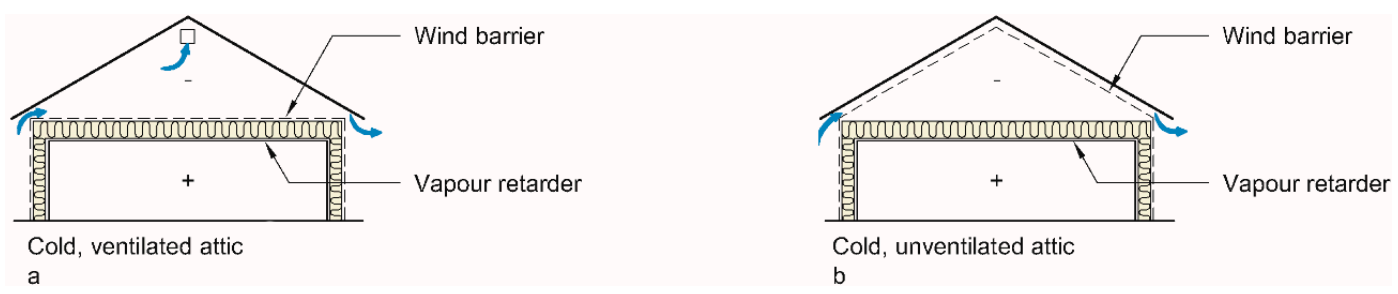

Figure 3. Roof Type $C$ with cold attic. (a) Cold, ventilated attic space with air stream flowing through the attic itself. (b) Cold, unventilated attic space with all ventilation between the underlayer roof and the roof covering. Image further developed from [16].

\subsection{Type D-Pitched Wooden Roofs with Heated Rooms in Part of the Attic}

Type D consists of roofs with heated rooms in part of the attic and is thoroughly described by [13]. This type of construction is, according to Uvsløkk, particularly vulnerable to moisture damage and heat loss from air leakages because the vapour retarder is not continuous through the floor construction. The construction type can be built up in two different ways, or a combination of these:

(a) Thermally non-insulated ventilated attic. The underlayer roofing can be vapour tight. There are ventilation openings in the ridge and between the underlayer roof and the thermal insulation along the purlin of the building. Ventilation openings have to be designed in order to avoid penetration of snow and rain into the attic. The vapour retarder and wind barrier are not continuous through the floor construction and the roof is therefore particularly vulnerable to moisture damage due to air leakages.

(b) Thermally insulated non-ventilated attic. The underlayer roof has to be vapour open. The construction is a further development of a) and an improved solution. It is possible to make a continuous and airtight joint between the wind barrier on the wall and the underlayer roof, thus making the construction more resistant to moisture compared to a).

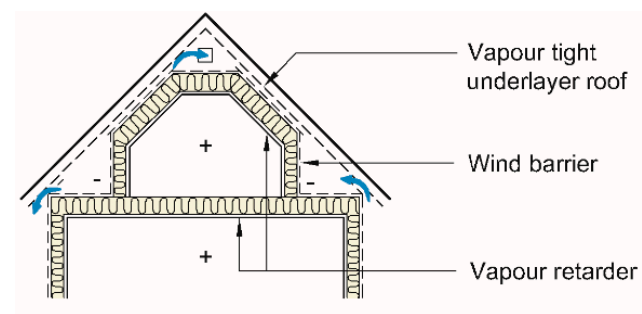

Noninsulated ventilated attic a

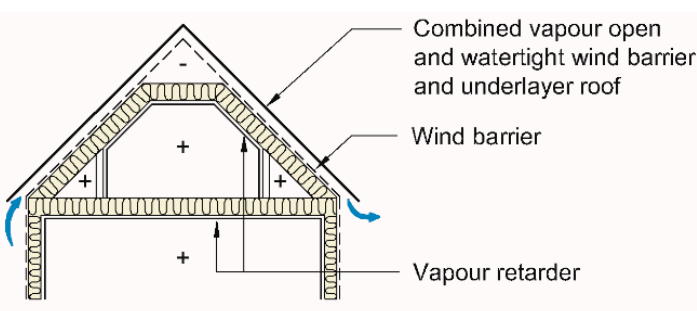

Insulated non ventilated attic b

Figure 4. Roof Type D with heated rooms in part of the attic. Thermally insulated non-ventilated attic rooms (a) and thermally non-insulated, ventilated (from outside) attic rooms (b). Further developed from [13]. 


\section{Analysis of Norwegian Roof Defects}

\subsection{SINTEF Building Defect Archive}

For more than 60 years, SINTEF Building and Infrastructure (formerly the Norwegian Building Research Institute) has been mapping building damage. The work has been performed both through extensive field investigations and on behalf of the construction and building industry. Detailed information about building defects has been collected and stored in an electronic archive. A thorough investigation into the process-induced building defects collected in this archive was performed by [10-12]. The study includes documents from the archive for the 10-year period from 1993 to 2002, which contains 2003 reports describing 2423 incidents or cases of defects. However, a thorough study of roof defects has not previously been conducted. Hence, this study looks in more detail at the cases concerning roof defects covered by [11,12]. The cases with roof defects account for 465 incidents [11,12].

Although a large archive, due to a relatively limited number of specific cases, the building defect archive may not represent a satisfactory description of all building defects in Norway. A relatively high cost related to the engagement of SINTEF has led to professional customers being the dominant share of the cases in the archive (as compared to private householders). Furthermore, it is likely that the archive includes major and expensive cases of building defects rather than smaller-scale and more private issues. One of the advantages of the archive is the large number of cases collected over a long period of time. In addition, the archive contains thorough and detailed descriptions of the defects and possible causes of the defects, and the documents are prepared by experts within the field. Therefore the building defects archive is particularly well suited to find typical building defects of different building constructions and the causes of these defects. The SINTEF building defect archive is acknowledged as one of Norway's most important sources of knowledge about building defects and defect sources.

\subsection{Building Defects Versus Source of Defect}

As Figure 5 shows, 22\% of the registered building defects are localized in roofs. Furthermore, $24 \%$ of the total building defects are caused by precipitation (see Table 1). It is worth noting that $75 \%$ of all defects are caused by moisture alone or as a consequence of moisture.

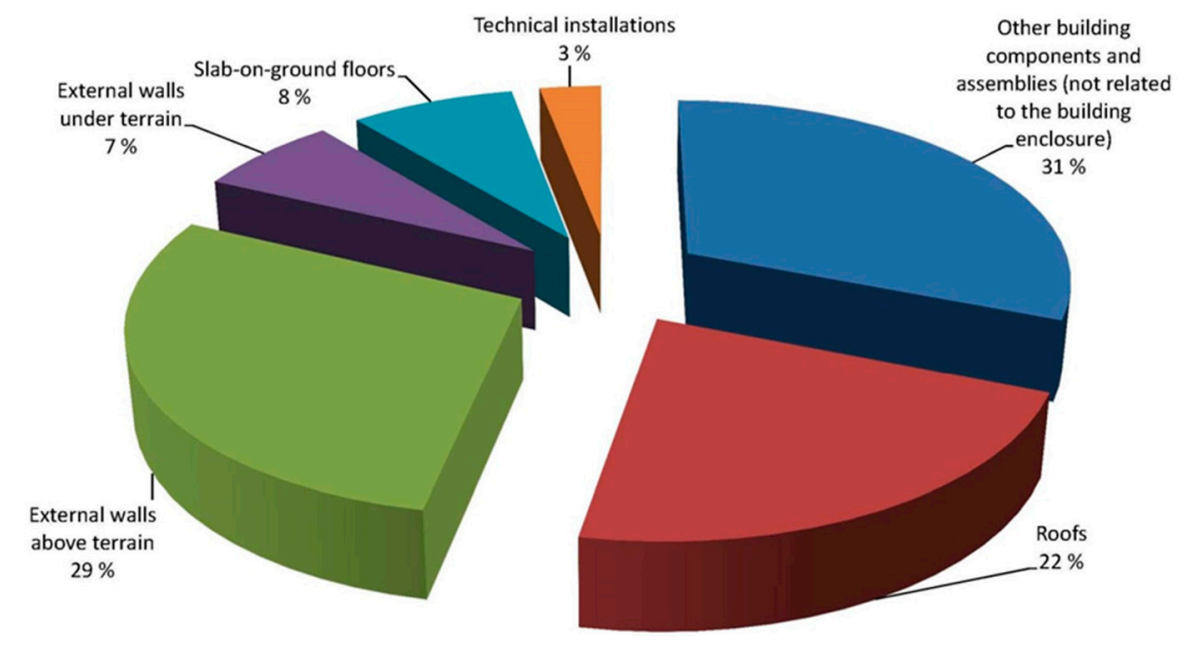

Figure 5. Process-induced building defect cases for the 10-year period from 1993-2002 (a total of 2423 building defect cases), distributed by localization of defects [12]. 
Table 1. Process-induced building defect cases for the 10-year period from 1993-2002, distributed by source of defects (critical exposure).

\begin{tabular}{|c|c|c|c|c|c|c|c|c|c|c|}
\hline & Selection & $\begin{array}{l}\text { Total Number of } \\
\text { Defect Cases }\end{array}$ & $\begin{array}{l}\text { Precipitation } \\
\quad(\%)\end{array}$ & $\begin{array}{c}\text { Indoor } \\
\text { Moisture (\%) }\end{array}$ & $\begin{array}{c}\text { Built-in } \\
\text { Moisture (\%) }\end{array}$ & $\begin{array}{l}\text { Water in } \\
\text { Soil (\%) }\end{array}$ & $\begin{array}{c}\text { Leakage Water } \\
\text { (from e.g., Sanitary } \\
\text { Installations) (\%) }\end{array}$ & $\begin{array}{l}\text { Combinations } \\
\text { of Moisture } \\
\text { Sources (\%) }\end{array}$ & $\begin{array}{l}\text { Sources of Moisture in } \\
\text { Combination with } \\
\text { Other sources (\%) }\end{array}$ & $\begin{array}{l}\text { Other Sources } \\
\text { (not Moisture } \\
\text { Related) (\%) }{ }^{(2)}\end{array}$ \\
\hline \multirow{2}{*}{\multicolumn{2}{|c|}{$\begin{array}{l}\text { Total amount of building defects } \\
\text { Total amount of roof cases }\end{array}$}} & 2423 & 24 & 15 & 6 & 8 & 5 & 9 & 9 & 24 \\
\hline & & 465 & 49 & 24 & 1 & 2 & 0 & 12 & 3 & 9 \\
\hline - & Compact roof cases ${ }^{(1)}$ & 83 & 51 & 22 & 2 & 0 & 1 & 13 & 2 & 8 \\
\hline- & $\begin{array}{l}\text { Terrace on concrete } \\
\text { floor cases }\end{array}$ & 121 & 78 & 8 & 1 & 5 & 0 & 4 & 2 & 2 \\
\hline- & $\begin{array}{l}\text { Pitched wooden roof } \\
\text { cases, total }\end{array}$ & 186 & 33 & 34 & 1 & 1 & 0 & 16 & 3 & 12 \\
\hline 0 & $\begin{array}{l}\text { Type A: Separate wind } \\
\text { barrier and underlayer roof }\end{array}$ & 33 & 33 & 42 & 0 & 0 & 0 & 12 & 3 & 9 \\
\hline O & $\begin{array}{l}\text { Type B: Combined wind } \\
\text { barrier and underlayer roof }\end{array}$ & 32 & 50 & 28 & 0 & 0 & 0 & 19 & 0 & 3 \\
\hline O & $\begin{array}{l}\text { Type C: Roofs with } \\
\text { cold attics }\end{array}$ & 58 & 34 & 24 & 0 & 1 & 0 & 16 & 5 & 19 \\
\hline O & $\begin{array}{l}\text { Type D: Roofs with heated } \\
\text { rooms in part of the attic }\end{array}$ & 63 & 24 & 41 & 2 & 1 & 0 & 16 & 3 & 13 \\
\hline
\end{tabular}

(1) A compact roof is a horizontal roof built up using inorganic insulation material and interior drainpipes. From the cold side of the construction, the roof is built up with a roofing membrane, insulation, a vapour retarder, and a load-bearing system; ${ }^{(2)}$ Examples of non-moisture-related sources of damage are overloading, lack of capacity, vibrations, wear, wrong material composition, insufficient frost protection, noise problems, temperature load/movements, UV radiation, chemical exposure, and assembly errors. 
Of the 465 cases registered in the roof category, $40 \%$ are in the pitched wooden roof category for Type A, B, C, and D (see Figure 6). The pitched wooden roof category is more thoroughly analysed in this study.

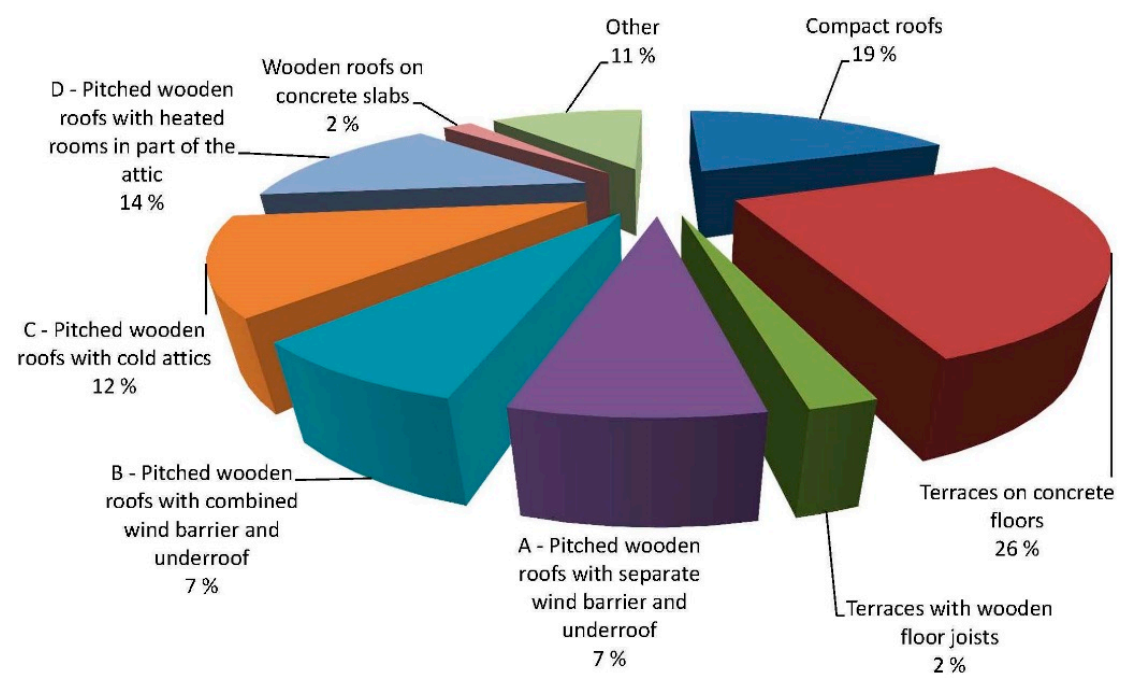

Figure 6. Defect cases for the 10-year period from 1993-2002 concerning roofs, distributed by type of roof (465 cases, $22 \%$ of the total amount of building defects) [12].

As much as $49 \%$ of the total roof defects are caused by precipitation and only $9 \%$ of the defects are not moisture related (see Table 1). Moisture from indoor air and precipitation are the dominating sources of defects in roofs (Table 1 ).

Table 1 also gives the defect source (critical exposure) distribution for each of the pitched wooden roof categories A, B, C, and D. Moisture from indoor air and precipitation account for $67 \%$ of the 186 cases with defects in pitched wooden roofs. Defects caused by indoor moisture are more frequent in the pitched wooden roof constructions.

Just over one-third (34\%) of the defects in the pitched roof category are caused by moisture in indoor air compared to $22 \%$ and $8 \%$ for the categories of compact roofs and terraces on concrete floors, respectively. Most of the damages caused by moisture in indoor air are in the Type A and D categories (approximately $40 \%$ of the cases). It is most likely that the increased rate of defects in Type D roofs is caused by condensation in the roof construction due to hot, humid indoor air leaking through joints in the vapour retarder (see Figures 7 and 8).

The distribution by source (critical exposure) of building defects in the different pitched wooden roof constructions is the main focus in this study. There are approximately twice as many defect cases registered in the roof categories Type $\mathrm{C}$ and $\mathrm{D}$ as compared to Type $\mathrm{A}$ and $\mathrm{B}$. This may indicate that Type $A$ and $B$ are more robust constructions than $C$ and $D$, but note that the numbers are not related to the number of constructions built.

\subsection{Typical Damage and Defects}

Typical damage and mistakes in thermally insulated pitched wooden roofs, according to findings from SINTEF's building defect archive, are summarized in Figure 7.

Together with indoor moisture, precipitation is the dominant source of climate exposure defects. Typical defect mechanisms are leaky roofing or fittings which in turn can lead to leakages through the roof construction. 


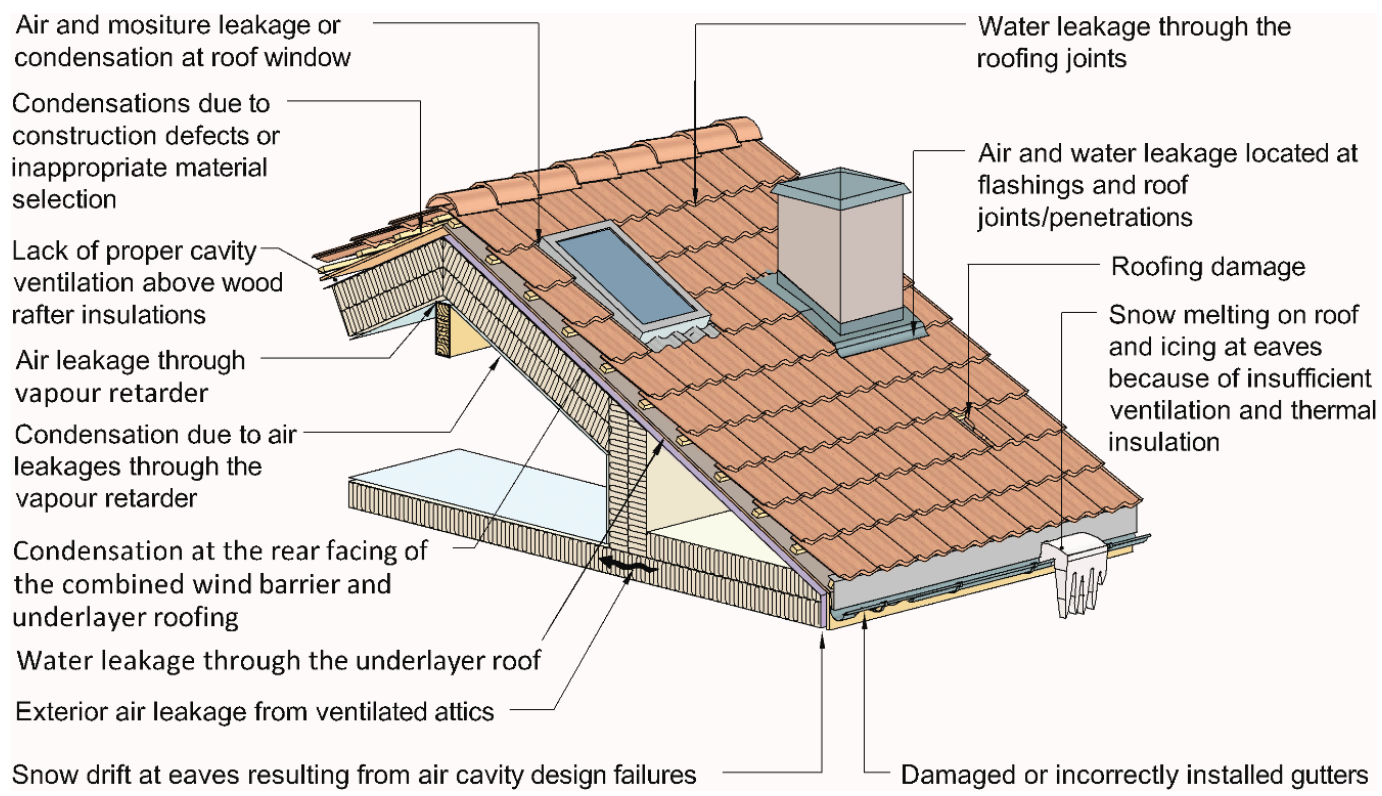

Figure 7. Typical defects in thermally insulated pitched wooden roofs according to findings from SINTEF's building defect archive.

Snow on the roofing creates an extra load that may be critical during snowy winters. In addition to the issue of how much snow is on the roof, the snow can melt and the water can freeze to ice. There can be different causes for the snowmelt (e.g., exterior climate such as rain and solar radiation exposure). Another cause can be lack of ventilation of the roofing in combination with a poorly insulated roof construction. Fresh snow has a relatively low thermal conductivity causing a temperature gradient through the snow [17]. The snow can therefore melt on the roofing even if the exterior temperature is significantly below $0{ }^{\circ} \mathrm{C}$. The water is transported downwards and freezes on the cold unheated parts of the roof, for example, the eaves and gutters. When ice builds up, this can dam up the water and make it penetrate the roofing. Gutters and drains can also be broken by ice formation (see Figure 7). Ice formation may also deteriorate roofing materials when it spreads down the roof $[18,19]$. The problem with snowmelt on roofs is found to be reduced in modern and well-insulated roofs with well-ventilated roofing [20].

Wind can cause periodic vibrations of roofing materials and may thus lead to material fatigue and crack formation [21]. Requirements for fastening of roofing are dependent on the type of roofing and the geographical location (wind exposure) of the actual building.

Condensation in the cold parts of the roof construction is, according to [22], often caused by air leakages through the vapour retarder. Condensation damage can occur given air leakages in the vapour retarder and internal overpressure (see Figure 8). The chimney effect causes overpressure in the upper parts of a building through the heating season. Examples of typical air leakages are shown in Figure 8. Generally, air leakages in the vapour retarder are critical, but in order to get air leakages through the entire roof construction, there must also be air leakages in the underlayer roof. Note that the risk of condensation damage increases with high humidity levels in the indoor air, which is often caused by poor ventilation of the indoor air. 

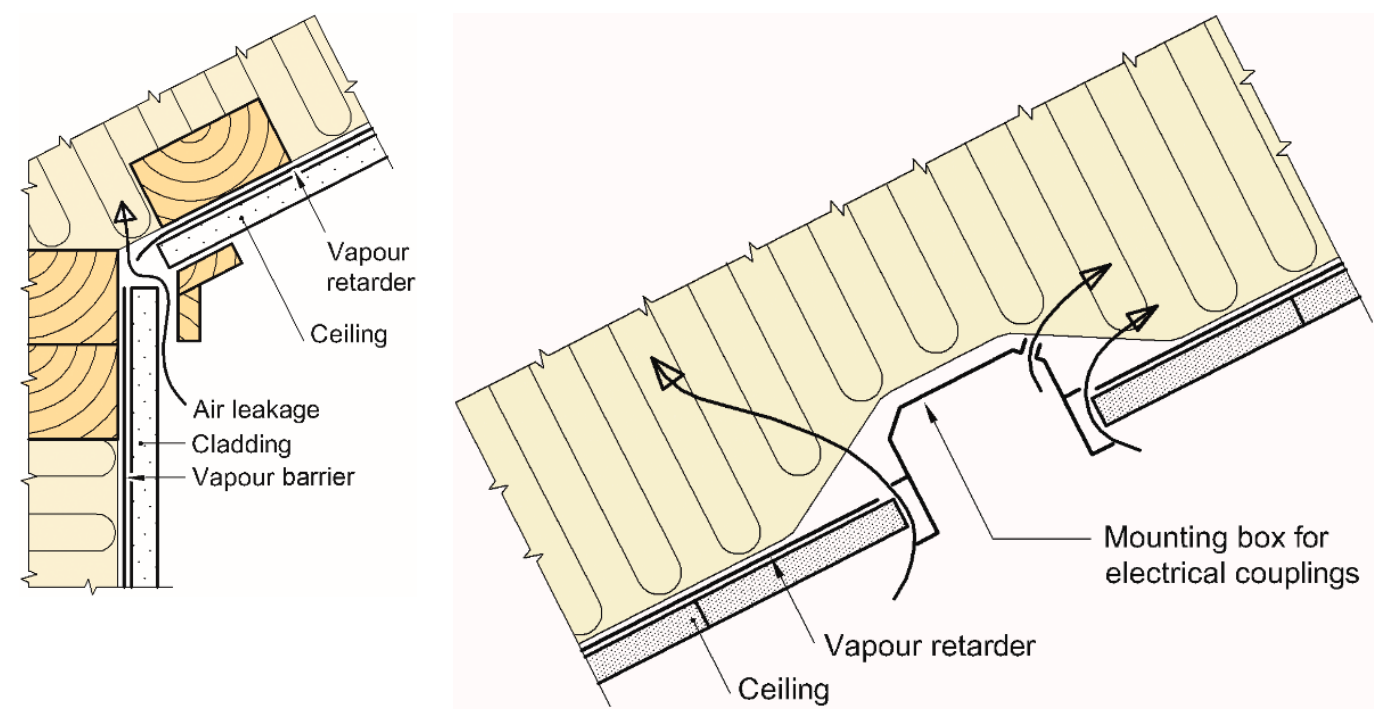

Figure 8. Examples of typical air leakage paths through the vapour retarder [20].

By securing a continuous airtight exterior wind barrier, the roof construction can be considered more moisture resistant. Air leakages through the vapour retarder may also be reduced when the exterior wind barrier is airtight.

\section{Discussion}

In the following section, the different roof constructions are discussed and compared.

\subsection{Type A-Pitched Wooden Roofs with Separate Wind Barrier and Roofing Underlay}

The study of the building defect archive shows that indoor moisture and moisture from precipitation are the main causes of defects. By comparing roof Type A with roof Type B, it seems that Type A has more damage from indoor moisture. A possible explanation for this is that Type B roofs are newer, possibly dating from the end of the 10-year period, while the instances of damage for Type A are registered in the beginning of the 10-year period. Towards the end of the 10-year period, the use of balanced indoor ventilation systems was more present, resulting in drier indoor air. Low moisture content in the indoor air helps to reduce the risk of building damage caused by moist indoor air. Towards the end of this 10-year period, there was also generally more focus in the construction industry on the importance of airtightness in the Norwegian building industry, resulting in reduced air leakage through the vapour retarder.

\subsection{Type B-Pitched Wooden Roofs with Combined Wind Barrier and Roofing Underlay}

Roof Type B is a more labour-efficient version of Type A because the wind barrier and the roofing underlay in roof Type A is replaced by one layer of vapour open and watertight membrane. Precipitation is a more frequent cause of damage compared to roof Type A. The single-layered solution of Type B can be considered more vulnerable to rain leakages compared to the two-layered solution in Type A. Type A therefore appears to be a better solution to avoid leakages from precipitation.

The Czech field investigations on roofing underlays performed by Dek [23] show low waterproof performance for combined underlayer roofs and wind barriers. A suggested explanation for the anticipated degradation of the underlayer roofs and the very poor results is the leaching of impregnation substances from the battens [23]. Low waterproof performance was also found in a field investigation performed by Brandt and Hansen [24]. If the waterproofing of the underlayer roofing is poor, the roof will be very vulnerable to water leakages through the roofing material. The watertightness of the roofing is dependent on the quality of both the roofing material and 
the workmanship. The results from the Czech [23] and Danish [24] field investigations do not correspond to accelerated ageing laboratory tests performed by SINTEF on various underlayer roofing products. Accelerated ageing tests on different underlayer roofing products have been performed by SINTEF in the accelerated climate simulator according to Nordtest Method NT Build 495 [25]. The accelerated ageing is based on an assessment that precipitation or driving rain, solar radiation, elevated temperatures, and cyclic freezing and thawing are critical exposure factors. Most of the tested products performed well, including after the durability tests had been completed. However, laboratory measurements can only describe an ideal reality. In practice, it is impossible to include all the possible effects, for example, from leaching of impregnated battens. As a result of the mismatch between the European field experiences $[23,24]$ and Norwegian laboratory findings, there is a need to perform further studies, and preferably a field investigation including various types of underlayer roofs in order to investigate the durability of underlayer roofs in the Norwegian climate.

\subsection{Type C - Pitched Wooden Roofs with Cold Attics}

Roof Type $\mathrm{C}$ can be built both with and without ventilation of the attic. A ventilated solution is more vulnerable to leakages in the vapour retarder at the ceiling of the roof compared to a non-ventilated solution which has a continuous exterior wind barrier. There are twice as many instances of damage in construction Type C compared to Type A and B. This could indicate that construction Type A and B are more robust compared to construction Type $C$ and $D$, although we know that the number is not related to the number of constructions built. A large part of the damage $(19 \%)$ is represented by other sources, with the common use of the attic as a storage area being an important reason for that.

\subsection{Type D-Pitched Wooden Roofs with Heated Rooms in Part of the Attic}

Roof Type D is rather common in Norwegian dwellings due to the efficient utilization of space. There are approximately $100 \%$ more building defect cases registered in this category compared to Type A and B. Many ( $41 \%)$ of the building defects are caused by indoor moisture. Type D has difficulties regarding airtightness of the floor construction; in particular, it is complicated to achieve a continuous and airtight joint of the vapour barrier in the floor construction (see Figure 4). As Figure 4 shows, the attic rooms can be ventilated, thus making the construction very vulnerable to air leakages from the inside.

Typical damage caused by indoor moisture include air leakages through the vapour barrier [20]. The driving force of the air leakage is internal overpressure caused by the stack (chimney) effect in the upper parts of the building. If the indoor ventilation is insufficient (i.e., high moisture supply), there is a risk of condensation.

By securing a continuous airtight exterior wind barrier, the roof construction can be considered more protected from moisture. Air leakages through the vapour retarder may also be reduced when the exterior wind barrier is more airtight than the vapour barrier.

\section{Conclusions}

Findings derived from SINTEF's building defect archive show that moisture is a dominant source of defects, especially in roof constructions. In pitched wooden roofs, $67 \%$ of the defects are caused by precipitation or indoor moisture. An airtight vapour retarder and use of balanced ventilation systems are effective means to prevent moisture damage from internal air. Furthermore, a favourable carbon footprint, a strong focus on $\mathrm{CO}_{2}$ emissions from buildings in general, and the development of zero emission buildings make wooden roofs suitable for an increasing number of large buildings. Thus, it is important to further increase the focus on robust solutions to avoid defects both from exterior and interior moisture sources in pitched wooden roofs.

Acknowledgments: The authors gratefully acknowledge the financial support by the Research Council of Norway and several partners through the Centre of Research-based Innovation "Klima 2050" (www.klima2050.no). 
Author Contributions: Lars Gullbrekken was responsible for the literature review and has been the main author of the paper. Tore Kvande has served as the main supervisor during the provess and gave feedback to successive rough drafts made by Lars Gullbrekken. In addition, he was responsible for the analysis of the building defects archive. Bjørn Petter Jelle and Berit Time have contributed with their extensive experience within the field of building physics, especially related to building enclosure performance. They have also during the process provided comments on the prepared manuscript.

Conflicts of Interest: The authors declare no conflict of interest.

\section{References}

1. O'Brien, K.; Sygna, L.; Haugen, J. Vulnerable or resilient? A multi-scale assessment of climate impacts and vulnerability in Norway. Clim. Change 2004, 64, 193-225. [CrossRef]

2. Lisø, K.; Time, B.; Kvande, T. Building enclosure performance in a more severe climate. In Research in Building Physics-Proceedings of the Second International Conference on Building Physics; A.A. Balkema Publishers: Leuven, Belgium, 2003; pp. 309-317.

3. Bauer, I.H.; Førland, E.J.; Haddeland, I.; Mayer, S.; Nesje, A.; Nilsen, J.E.Ø.; Sandven, S.; Sandø, A.B.; Sorteberg, A.; Ådlandsvik, B. Klima i Norge 2100 (Climate in Norway 2100); Norwegian environment Agency: Oslo, Norway, 2015. (In Norwegian)

4. Jelle, B.P. Accelerated climate ageing of building materials, components and structures in the laboratory. J. Mater. Sci. 2012, 47, 6475-6496. [CrossRef]

5. Jelle, B.P.; Breivik, C.; Røkenes, H.D. Building integrated photovoltaic products: A state-of-the-art review and future research opportunities. Solar Energy Mater. Sol. Cells 2012, 100, 69-96. [CrossRef]

6. Breivik, C.; Jelle, B.P.; Time, B.; Holmberget, Ø.; Nygård, J.; Bergheim, E. Large-scale experimental wind-driven rain exposure investigations of building integrated photovoltaics. Sol. Energy 2013, 90, 179-187. [CrossRef]

7. Gullbrekken, L.; Kvande, T.; Time, B. Roof-integrated PV in nordic climate-Building physical challenges. Energy Proced. 2015, 78, 1962-1967. [CrossRef]

8. Jelle, B.P.; Sveipe, E.; Wegger, E.; Gustavsen, A.; Grynning, S.; Thue, J.V.; Time, B.; Lisø, K.R. Robustness classification of materials, assemblies and buildings. J. Build. Phys. 2014, 37, 213-245. [CrossRef]

9. Ingvaldsen, T. Byggskadeomfanget $i$ Norge en Vurdering Basert På et Tidligere Arbeid og Nye Data (Building Defects in Norway an Assessment Based on Earlier Work and New Data); Prosjektrapport 17; SINTEF Byggforsk: Oslo, Norway, 2008. (In Norwegian)

10. Kvande, T.; Lisø, K.R. Climate adapted design of masonry structures. Build. Environ. 2009, 44, $2442-2450$. [CrossRef]

11. Lisø, K.R.; Kvande, T.; Thue, J.V. Research in Building Physics and Building Engineering; Tyler \& Francis: Oxford, UK, 2006; pp. 425-432.

12. Lisø, K.R.; Kvande, T.; Vincent, J.V. The Robustness of the Norwegian Building Stock-A Review of the Process Induced Building Defects. In Proceedings of the 7th Symposium on Building Physics in the Nordic Countries, Reykjavík, Iceland, 13-15 June 2005.

13. Edvardsen, K.; Ramstad, T. Trehus Håndbok 5 (Wooden Houses Handbook No 5); SINTEF Building and Infrastructure: Oslo, Norway, 2014. (In Norwegian)

14. Pedersen, T.E.; Bakken, N.; Time, B. Regntetthet for Kombinerte Undertak og Vindsperrer på Rull (Raintightness of Combined Underlayer Roofings and Wind Barriers); Prosjektrapport 23; SINTEF Building and Infrastructure: Trondheim, Norway, 2008. (In Norwegian)

15. Hagentoft, C.-E.; Sasic Kalagasidis, A. Moisture safe cold attics-Assessment based on risk analyses of performance and cost. In Proceedings of the 10th Nordic Symposium on Building Physics, Lund, Sweden, 15-19 June 2014.

16. Lisø, K.; Kvande, T. Klimatilpassing av Bygninger (Climate Adaption of Buildings); SINTEF Building and Infrastructure: Oslo, Norway, 2007. (In Norwegian)

17. Calonne, N.; Flin, F.; Morin, S.; Lesaffre, B.; Du Roscoat, S.R.; Geindreau, C. Numerical and experimental investigations of the effective thermal conductivity of snow. Geophys. Res. Lett. 2011, 38, 1-6. [CrossRef]

18. Juul, H.; Bøhlerengen, T. Ising på Tak En Studie av et Skadetilfelle (Ice Formation on Roofs-A Study of Damages); Norwegian Building Research Institute: Oslo, Norway, 1990. (In Norwegian)

19. Lossius, P.; Bøhlerengen, T. Takstein Snø og Brekkasje (Concrete Roofing, Snow and Damage); Prosjektrapport 67; Norwegian Building Research Institute: Oslo, Norway, 1990. (In Norwegian) 
20. Geving, S. Fuktskader Årsaker, Utbedringer og Tiltak (Moisture Damage: Reasons, Improvements and Actions); SINTEF Building and Infrastructure: Oslo, Norway, 2011.

21. Mahendran, M. Fatigue Behaviour of Corrugated Roofing under Cyclic Wind Loading; James Cook University of North Queensland: Queensland, Australia, 1990.

22. Uvsløkk, S. Moisture and temperature conditions in cold lofts and risk of mould growth. In Proceedings of the Nordic Building Conference, Tampere, Finland, 29 May-2 June 2011.

23. Dek, A. Research on the Lifetime of Membranes. DEKTIME Special 01; Atelier Dek: Prague, Czech, 2012.

24. Brandt, E.; Hansen, E.J. Durability of roof underlays exposed to long time exposure under in-use conditions. In Proceedings of the XIII International Conference on Durability of Building Materials and Components, Sao Paulo, Brazil, 2-5 September 2014.

25. Nordtest Method NT BUILD 495 Building Materials and Components in the Vertical Position: Exposure to Accelerated Climatic Strains; Nordtest: Espoo, Finland, 2000.

(C) 2016 by the authors; licensee MDPI, Basel, Switzerland. This article is an open access article distributed under the terms and conditions of the Creative Commons Attribution (CC-BY) license (http://creativecommons.org/licenses/by/4.0/). 